\title{
References
}

1. Vasilieva L.M. Poniattia i sutnist pidpryiemnytstva. Visnyk Dnipropetrovskoho derzhavnoho ahrarnoho universytetu. 2010. No.1. p.175-178 [in Ukrainian].

2. Vlasova N.O., Chorna M.V., Bieliaieva M.V. Ekonomichnyi mekhanizm rehuliuvannia pidpryiemnytskoii diialnosti v rozdribnii torhivli: monohrafiia. Kharkiv:KHDUKHT, 2013. 155 p. [in Ukrainian].

3. Syzonenko V. Teoriia pidpryiemnytstva: zdobutky I problem doslidzhennia. Ekonomika Ukrainy.2002. No.9 p.45-51 [in Ukrainian].

4. Androsova T.V. Torhivlia v rynkovii ekonomitsi: navch. Posibnyk. Kharkiv: KHDUKHT, 2001. 120 p. [in Ukrainian].

5. Burak I.O. Kontseptualni pidkhody do vyznachennia sutnosti ta vydiv torhovelnoi diialnosti. Molodyi vchenyi. 2016. No.3(30). [in Ukrainian].

6. Vlasova N.O., Krasnousov A.V. Teoretychni aspekty zmistu „komertsiinio diialnosti” pidpryiemstv torhivli. Ekonomika rozvytku. KHNEU. 2005. No.2 (34). P. 66-68.

7. Pankratov F.H., Sierohina T.K. Komertsiina sprava: navchalnyi osibnyk. 2-he vydannia, vypravlene Rivne: Verteks, 2009. 352 p. [in Ukrainian].

8. Sabluk O. Sut i pryntsypy komertsiinoho pidpryiemnytstva i komertsiinoi diialnosti. Naukovyi visnyk MNU imeni V.O. Sukhomlynskoho. Ekonomichni nauky. 2018. No.1(10) [in Ukrainian].

Дата подання публікації 25.12.2020 р.

Косінський П.М., доктор філософії Асистент кафедри економіки Kosinskyi P., $\mathrm{PhD}$ Assistant of the Department of Economics https://orcid.org/0000-0002-3254-2379

\section{ОЦІНКА НЕОБХІДНОСТІ ЗАСТОСУВАННЯ ДОДАТКОВИХ ЕКОНОМІЧНИХ ІНСТРУМЕНТІВ ЗНИЖЕННЯ ВИКИДІВ І ВІДХОДІВ ПЕРЕРОБНИХ ВИРОБНИЦТВ У РЕГІОНІ}

\author{
Луцький національний технічний університет
}

\begin{abstract}
В статті розглядається питання, що стосується застосування додаткових економічних стимулів як засобів впливу на зниження викидів і відходів переробних виробництв регіону, що працюють на місцевій природно-ресурсній сировині. Визначено фактори, які впливають на викиди шкідливих речовин та відходів у навколишне природне середовище. Узагальнено «основні проблеми функціонування системи стимулювання поглибленої переробки природних ресурсів еколого-економічного характеру. Виявлено, що у Волинській області спостерігається переважно позитивна тенденція до збільшення масштабів поглибленої переробки природної сировини, а також доцільності збільшувати бюджетні видатки на розвиток сільського, лісового та рибного господарства, адже це дасть позитивний соціально-економічний результат. Вивчено й проаналізовано тенденції стосовно зміни обсягів реалізації промислової продукції та зміни обсягів викиду шкідливих речовин і відходів, на основі показників реальних обсягів реалізації продукції підприємств харчової та деревообробної сфери, дослідження яких показало, що за останнє десятиріччя обсяг реалізованої продукції підприємствами деревообробної та харчової сфер промисловості регіону поступово зростав, при чому обсяг відходів та викидів шкідливих речовини, в наслідок їхньої діяльності, поступово зменшувався, що, зрештою, дає можливість говорити про певний розвиток поглибленої переробки природних деревинних ресурсів і сільськогосподарської сировини у Волинській області. Проведено порівняння показників співвідношення обсягів виробництва (реалізації) продукції підприємствами, що переробляють місцеву природно-ресурсну сировину до суми обсягів відходів виробництва й викиду шкідливих речовин в звітному році із середнім зваженим значенням даного показника за період 2010-2018 pp. Таким чином, коли щорічний показник співвідношення обсягів реалізації продукції підприємствами, до сумарного обсягу відходів виробництва й викиду шкідливих речовин більший за середнє зважене значення, то відпадає потреба у залученні додаткових економічних інструментів зниження обсягів забруднюючих речовин, але, якщо даний показник є меншим за середнє зважене значення, то залучення додаткових економічних інструментів зниження викидів і відходів переробних виробництв у регіоні $\epsilon$ просто необхідним. У зв'язку з цим, запропоновано використовувати відповідні фінансово-економічні інструменти заохочувального та карального характеру.
\end{abstract}


Ключові слова: поглиблена переробка; переробні виробнищтва; економічні інструменти; природні ресурси; екологічно чисті виробництва; інноваційне обладнання.

\title{
ASSESSMENT OF THE NEED FOR APPLICATION OF ADDITIONAL ECONOMIC INSTRUMENTS TO REDUCE EMISSIONS AND WASTE OF PROCESSING PRODUCTIONS IN THE REGION
}

\author{
Lutsk National Technical University
}

\begin{abstract}
The article considers the issue of using additional economic incentives as a means of influencing the reduction of emissions and waste from processing industries in the region, working on local natural resources. Factors influencing emissions of harmful substances and wastes into the environment have been identified. The "main problems of functioning of the system of stimulation of in-depth processing of natural resources of ecological and economic character are generalized. It was found that in Volyn region there is a mostly positive trend to increase the scale of in-depth processing of natural raw materials, as well as the feasibility of increasing budget expenditures for the development of agriculture, forestry and fisheries, because it will give a positive socioeconomic result. The tendencies concerning change of volumes of industrial production and change of volumes of emission of harmful substances and wastes are studied and analyzed, on the basis of indicators of real volumes of realization of production of the enterprises of food and woodworking sphere which research has shown. gradually increased, and the volume of waste and emissions of harmful substances, as a result of their activities, gradually decreased, which, ultimately, gives the opportunity to talk about a certain development of in-depth processing of natural wood resources and agricultural raw materials in Volyn region. A comparison of the ratio of production (sales) of enterprises processing local natural resources to the amount of waste production and emissions of harmful substances in the reporting year with the weighted average value of this indicator for the period 20102018. Thus, when the annual indicator the ratio of sales by enterprises to the total volume of production waste and emissions is greater than the weighted average, there is no need to attract additional economic instruments to reduce pollutants, but if this figure is less than the weighted average, the involvement of additional economic tools to reduce emissions and waste from processing industries in the region is simply necessary. In this regard, it is proposed to use appropriate financial and economic instruments of incentive and punitive nature.

Keywords: in-depth processing; processing industries; economic instruments; natural resources; environmentally friendly production; innovative equipment.
\end{abstract}

Постановка проблеми у загальному вигляді та ії зв'язок з важливими науковими та практичними завданнями. Коли йде мова про доцільність розвитку переробних виробництв, а саме про можливості поглибленої переробки природної сировини, розширення стадій виробництва, перш за все звертаємо увагу на можливий економічний ефект (додатковий прибуток), що можна отримати внаслідок зростання доданої вартості природного ресурсу на кожному етапі промислового виробництва.

Але варто звернути увагу на те, що фактично будь-яке промислове виробництво супроводжується викидами шкідливих речовин та відходів у навколишнє природне середовище, що, ясна річ, завдає певний удар по сформованій роками екосистемі, що, в свою чергу, призводить до порушення балансу в ній. Звісно, обсяги викидів шкідливих речовин і відходів у навколишнє природне середовище тим, чи іншим промисловим підприємством залежить від низки факторів, зокрема: рівня інноваційного розвитку промислового підприємства; рівня його екологічної культури; концепції, яку воно поклало в основу своєї діяльності; спрямованості на задоволення соціально-екологічних чи соціально-економічних потреб населення, або на забезпечення оптимального балансу між ними; наявної фінансово-ресурсної бази для забезпечення ресурсоощадного та безвідходного виробництва тощо.

Безумовно, в нашій державі потрібно провадити поглиблену переробку природних ресурсів, забезпечувати комплексне їх використання, при чому, вона повинна зумовлювати не лише збереження наявного рівня екологічного стану навколишнього природного середовища, іншими словами, не погіршувати його, а й навпаки - сприяти його поліпшенню, раціональному використанню природних ресурсів їх відтворенню.

Аналіз останніх досліджень і публікацій, в яких започатковано вирішення проблеми. Дослідженнями, що стосуються екологічних проблем навколишнього природного середовища займалися С.М. Домбровська, В.В. Коврегін, О.В. Латишава [1; 
2], які вивчали загальні проблеми екологічної сфери нашої держави, іiі зміни внаслідок діяльності і шкідливого впливу промислових підприємств, робили відповідні прогнози й давали рекомендації щодо запобігання й уникнення негативного впливу галузей національної промисловості на стан навколишнього природного середовища. Теоретичні питання впливу фінансово-економічних інструментів на розвиток виробництв із поглибленої переробки природних ресурсів досліджували А.А. Теребух, Г.Я. ІльницькаГикавчук, О.П. Макар [3], О.В. Файчук [4], В.Г Поліщук [5], М.I. Карлін [6] та інші дослідники. Проте в джерелах наукової літератури не достатньо повно розкритим $\epsilon$ питання доцільності використання економічних інструментів 3 метою зниження викидів і відходів переробних виробництв. Не дано чіткої відповіді стосовно того, чи завжди поглиблена переробка дає одночасно позитивний економічний, соціальний та екологічний ефект, чи завдана екологічна шкода (можливо, на перши погляд, незначна) компенсується за рахунок соціально-економічних вигод суспільства, а також відносно того, що на даному етапі розвитку нашої держави може виступати додатковим економічним інструментом зниження викидів і відходів переробних виробництв.

Мета статті полягає у тому, щоб на прикладі Волинської області дослідити як розвиток переробних виробництв, зокрема поглибленої переробка сировинних ресурсів на них, впливає на обсяги викидів шкідливих речовин й відходів, одержаних в результаті ïx діяльності, а також визначити додаткові економічні інструменти, що можуть стимулювати суб'єктів господарювання до зниження даних показників.

Виклад основного матеріалу дослідження 3 повним обгрунтуванням отриманих наукових результатів. На основі досліджень С.С. Нешик та О.В. Сяськи нами було узагальнено «основні проблеми функціонування системи стимулювання поглибленої переробки природних ресурсів еколого-економічного характеру, а саме:

- відсутність погодженої і досконалої системи повноважень спеціальноуповноважених органів влади щодо природокористування і охорони довкілля;

- відсутність еколого-економічного механізму запобігання інтенсивному використанню природних ресурсів, що здійснює антропогенний вплив на навколишнє середовище;

- низький рівень соціально-екологічної відповідальності суб'єктів природокористування;

- відсутність правових норм прямої дії в екологічному законодавстві;

- недостатня забезпеченість переробних підприємств фінансовими ресурсами на запобіжні еколого-економічні заходи в природно-ресурсній сфері тощо» [7-9].

Що конкретно стосується Волинської області, то «виявлено, що регіон демонструє переважно позитивну тенденцію до збільшення масштабів поглибленої переробки природної сировини, а тому доцільно збільшувати бюджетні видатки на розвиток сільського, лісового та рибного господарства, адже це дасть позитивний соціально-економічний результат» [9].

Однак питання зниження викидів забруднюючих речовин й відходів у навколишнє природне середовище підприємствами переробної сфери промисловості досліджуваного регіону залишається відкритим.

В Україні законодавчо встановлені ліміти (дозволені норми) викиду шкідливих речовин та відходів у навколишнє середовище за перевищення яких передбачено адміністративну й кримінальну відповідальність.

Однак, встановлені природоохоронним законодавством покарання за нанесення шкоди навколишньому природному середовищу в наслідок «недобросовісного» природокористування, порівняно із можливим обсягами нанесеної екологічної шкоди фактично $є$ неспівставними, не відповідають дійсності й вже давно не викликають страху у природокористувачів за скоєну шкоду.

Як зазначає О.В. Стоян «штрафи за порушення встановлених екологічних норм та правил в нашій державі вже давно втратили стимулюючий вплив на природокористувачів , є малоефективними та досить м'якими» [10]. 
На нашу думку, в нашій державі єдиним дієвим й ефективним інструментом, що здатний вплинути на регулювання обсягів викиду шкідливих речовин й відходів у навколишнє природне середовище переробними підприємствами є екологічний податок. Тому, щоб дійсно домогтися вагомого зниження обсягів викиду забруднюючих речовин у навколишнє середовище потрібно розглядати можливість застосування додаткових економічних стимулів для досягнення цієї мети.

Для того, щоб оцінити необхідність застосування додаткових економічних інструментів для зниження обсягів забруднюючих речовин і відходів переробних підприємств, наявних у Волинській області, пропонуємо, перш за все, вивчити й проаналізувати тенденції зміни даних показників й показників обсягів реалізації (виробництва) промислової продукції. на підприємствах харчової та деревообробної промисловості, так як вони, на нашу думку, у даному регіоні характеризуються найвищим ступенем поглибленої переробки природно-ресурсної сировини.

Також, на основі вищенаведених даних, вважаємо необхідним розрахувати показники співвідношення обсягів реалізації продукції підприємствами, що переробляють місцеву природно-ресурсну сировину до суми обсягів відходів виробництва й викиду шкідливих речовин, використавши для цього формулу:

$$
\mathrm{E}_{\text {екол }}=\frac{Q_{\text {реал }}}{Q_{\text {відх }}+Q_{\text {шра }}},
$$

де: $\mathrm{E}_{\text {екол }}$ показник співвідношення обсягів реалізації продукції підприємствами, що переробляють місцеву природно-ресурсну сировину до суми обсягів відходів виробництва й викиду шкідливих речовин;

Qреал - реальні обсяги реалізації продукції харчових та деревообробних підприємств (скориговані на кумулятивний індекс споживчих цін);

$\mathrm{Q}_{\text {відх }}$ обсяги відходів деревообробних та харчових підприємств;

$\mathrm{Q}_{\text {шра }}$ - обсяг викиду шкідливих речовин в атмосферу підприємствами харчової та деревообробної сфер промисловості.

Дані розрахунків показників співвідношення обсягів реалізації продукції підприємствами, що переробляють місцеву природно-ресурсну сировину до суми обсягів відходів виробництва й викиду шкідливих речовин наведено в таблиці 1.

Таблиця 1

Аналіз зміни обсягів реалізації продукції підприємств харчової та деревообробної промисловості та обсягів відходів і шкідливих викидів даних підприємств у Волинській області за період 2010-2018 pp.

\begin{tabular}{|c|c|c|c|}
\hline Роки & $\begin{array}{c}\text { Реальний обсяг реалізації } \\
\text { продукції підприємств } \\
\text { харчової та } \\
\text { деревообробної } \\
\text { промисловості } \\
\text { (скоригований на } \\
\text { кумулятивний індекс } \\
\text { споживчих цін), млн. грн }\end{array}$ & $\begin{array}{c}\text { Обсяги відходів і } \\
\text { шкідливих викидів } \\
\text { підприємств харчової та } \\
\text { деревообробної } \\
\text { промисловості, млн. т }\end{array}$ & $\begin{array}{c}\text { Показник співвідношення обсягів } \\
\text { реалізації продукції } \\
\text { підприємствами, що } \\
\text { переробляють місцеву природно- } \\
\text { ресурсну сировину до суми } \\
\text { обсягів відходів виробництва й } \\
\text { викиду шкідливих речовин (Екол), } \\
\text { грн/т }\end{array}$ \\
\hline 2010 & 3699,1 & 335,3 & 11,0 \\
\hline 2011 & 4411,7 & 306,9 & 14,4 \\
\hline 2012 & 4685,5 & 276,9 & 37,3 \\
\hline 2013 & 4626,5 & 124,1 & 33,0 \\
\hline 2014 & 4638,3 & 140,4 & 31,2 \\
\hline 2015 & 4866,5 & 156,1 & 23,7 \\
\hline 2016 & 4588,5 & 193,5 & 22,0 \\
\hline 2017 & 5056,5 & 229,4 & 24,8 \\
\hline 2018 & 5271,2 & 212,4 & 37,3 \\
\hline
\end{tabular}

Джерело: авторська розробка на основі [11-13]. 
Таким чином бачимо, що впродовж 2010-2018 років у Волинській області реальний обсяг реалізації продукції підприємств харчової та деревообробної промисловості (скоригований на кумулятивний індекс споживчих цін) зріс на 1572,1 млн. грн (42,5\%). При цьому, обсяги відходів і шкідливих викидів підприємств харчової і деревообробної промисловості зменшились на 122,9 млн. т (36,7\%). Але варто звернути увагу на те, що збільшення обсягів реалізації продукції зазначених сфер промисловості може свідчити не про зростання обсягів виробництва, а про збільшення іiї вартості, проте, поступове зниження викиду шкідливих речовин і відходів, зрештою дає можливість говорити про певний розвиток поглибленої переробки природних деревинних ресурсів $\mathrm{i}$ сільськогосподарської сировини у Волинській області.

На таку думку також наводять зміни показників співвідношення обсягів реалізації підприємств даних сфер промисловості до суми обсягів відходів виробництва й викиду шкідливих речовин. Якщо в 2010 році на 1 т шкідливих викидів і відходів підприємств харчової та деревообробної промисловості припадало 11,0 грн від обсягу реалізованої продукції, то в 2018 році - на 1 т шкідливих викидів і відходів даних підприємств припадало вже 24,8 грн.

Для більш повного формування висновків щодо залучення додаткових економічних інструментів стимулювання зменшення обсягів забруднюючих речовин в навколишнє середовище, порівняємо показник співвідношення обсягів виробництва (реалізації) продукції підприємствами, що переробляють місцеву природно-ресурсну сировину до суми обсягів відходів виробництва й викиду шкідливих речовин в звітному році із середнім зваженим значенням даного показника за період 2010-2018 рр.. Відповідно середнє значення вище зазначених показників обчислюватиметься за формулою:

$$
\overline{\mathrm{E}_{\text {екол }}}=\frac{Q_{\text {реал 1 }} \cdot \mathrm{E}_{\text {екол } 1}+Q_{\text {реал 2 }} \cdot \mathrm{E}_{\text {екол } 2}+\cdots+Q_{\text {реал } n} \cdot \mathrm{E}_{\text {екол } n}}{Q_{\text {реал } 1}+Q_{\text {реал 2 }}+\cdots+Q_{\text {реал } n}},
$$

де: $\overline{\mathrm{E}_{\text {екол }}}-$ середній показник співвідношення обсягів реалізації продукції підприємствами, що переробляють місцеву природно-ресурсну сировину до суми обсягів відходів виробництва й викиду шкідливих речовин;

$Q_{\text {реал1,2,n }}$ - реальні обсяги реалізації продукції підприємств, що займаються переробкою місцевої природної сировини в $1,2, n$-періоді;

$\mathrm{E}_{\text {екол 1,2n }}$ - показник співвідношення обсягів виробництва (реалізації) продукції підприємствами, що переробляють місцеву природно-ресурсну сировину до суми обсягів відходів виробництва й викиду шкідливих речовин.

Результати добутку реальних обсягів реалізації продукції підприємств, що займаються переробкою місцевої природної сировини й показників співвідношення обсягів виробництва (реалізації) продукції підприємствами, що переробляють місцеву природно-ресурсну сировину до суми обсягів відходів виробництва й викиду шкідливих речовин подано в таблиці 2.

Таблиця 2

Результати добутку реальних обсягів реалізації продукції й показників співвідношення реалізованої продукції підприємств харчової та деревообробної промисловості до суми обсягів відходів виробництва й викиду шкідливих речовин (млн грн / т)

\begin{tabular}{|r|r|r|r|r|r|r|r|r|}
\hline \multicolumn{10}{|c|}{ Роки } \\
\hline 2 & 2 & 2 & 20 & 20 & 20 & 20 & 20 & \multicolumn{1}{c|}{20} \\
\hline 4 & 011 & 012 & 13 & 14 & 15 & 16 & 17 & 18 \\
0690,1 & 3528,5 & 9185,0 & 2568,5 & 3063,9 & 1834,8 & 8747,5 & 1243,0 & 0725,8 \\
\hline
\end{tabular}


Джерело: авторська розробка на основі [11-13].

Таким чином, згідно вище поданої формули й даних, розрахуємо середній показник співвідношення обсягів реалізації продукції підприємствами, що переробляють місцеву природно-ресурсну сировину до суми обсягів відходів виробництва й викиду шкідливих речовин $\left(\overline{\mathrm{E}_{\text {екол }}}\right)$ :

$$
\begin{aligned}
\overline{\mathrm{E}_{\text {екол }}}= & \frac{40690,1+63528,5+79185,0+172568,5+153063,9+151834,8+108747,5+111243,0+130725,8}{3699,1+4411,7+4685,5+4626,5+4638,3+4866,5+4588,5+5056,5+5271,2}= \\
& =24,2(\text { грн / т) }
\end{aligned}
$$

Щоб зробити відповідні висновки про оцінку та доцільність необхідності застосування додаткових економічних інструментів зниження викидів і відходів переробних виробництв у досліджуваному регіоні, вважаємо за потрібне провести порівняння щорічного та середнього зваженого показника співвідношення обсягів реалізації продукції підприємствами, що переробляють місцеву природно-ресурсну сировину до сумарного обсягу відходів виробництва й викиду шкідливих речовин (рис. 1).

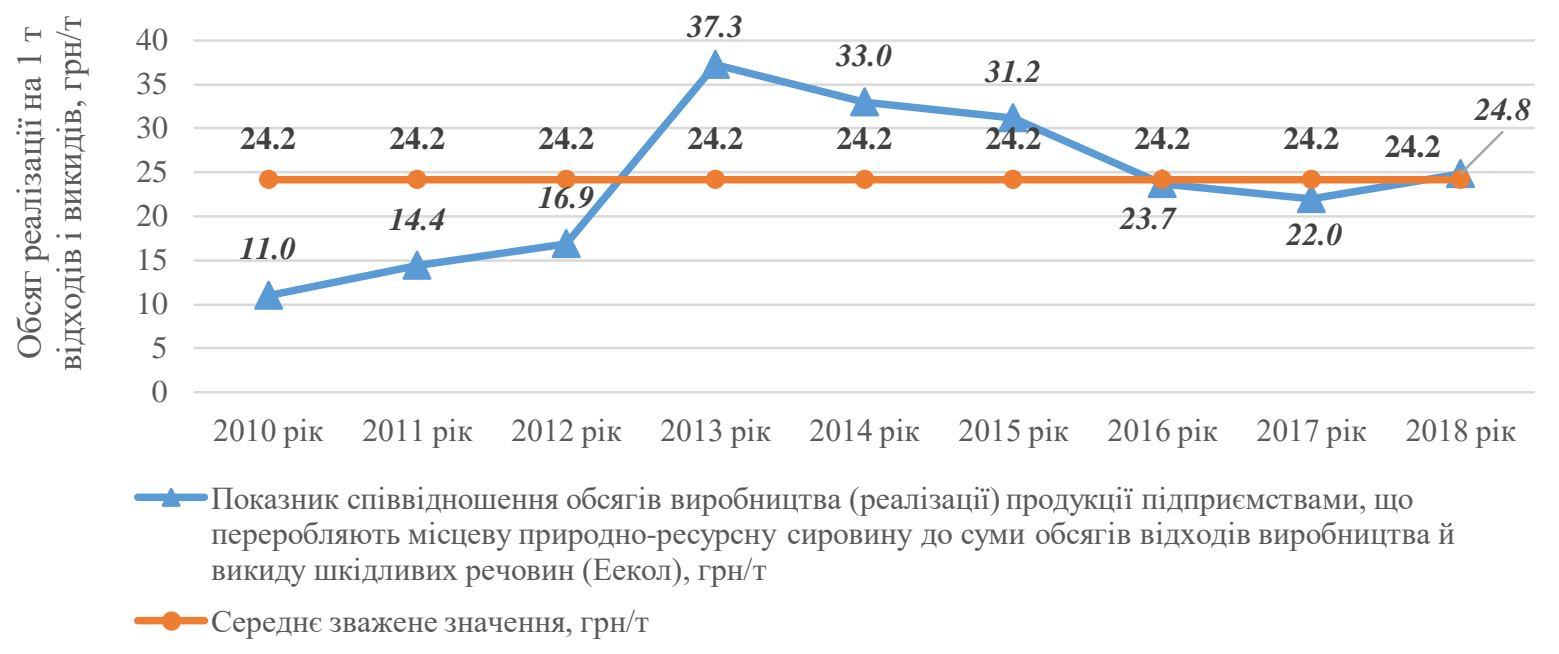

Рис. 1. Порівняння щорічного та середнього зваженого показника співвідношення обсягів реалізації продукції підприємствами, що переробляють місцеву природно-ресурсну сировину до сумарного обсягу відходів виробництва й викиду шкідливих речовин (побудовано автором)

На основі даних рисунку 1 можна зробити висновки, що коли щорічний показник співвідношення обсягів реалізації продукції підприємствами, що переробляють місцеву природно-ресурсну сировину до сумарного обсягу відходів виробництва й викиду шкідливих речовин більший за середнє зважене (планове, прогнозне) значення, то до переробних підприємств не має особливої потреби в залучати додаткові економічні інструменти стимулювання зниження обсягів забруднюючих речовин, навіть в деяких випадках, для досягнення більш кращого результату, можна застосовувати певні засоби заохочення. Але, якщо даний показник $\epsilon$ меншим за середнє зважене (планове, прогнозне) значення, то залучення додаткових економічних інструментів зниження викидів і відходів переробних виробництв у регіоні (переважно карального характеру) $є$ просто необхідним.

Як відомо, ресурсоощадне та «екологічно чисте» обладнання для переробних виробництв, а також впровадження інновацій у даному напрямку, потребують значних 
капіталовкладень і тому, без державної допомоги розвиток таких виробництв у Волинській області, значно уповільнюється.

Зокрема, упродовж останніх років «видатки місцевих бюджетів на розвиток сільського, лісового господарств, рибальства й мисливства в структурі загальних видатків місцевих бюджетів не перевищувала $0,5 \% »$, що свідчить про неефективність державних фінансових стимулів та системи фінансового стимулювання загалом [10].

Для прикладу, упродовж 2014-2017 років, «фінансування інноваційної діяльності переробних підприємств Волинської області щонайменше на 88,7\% здійснювалося за рахунок власних коштів, а решта - за рахунок кредитних» [14].

Висновки. Поглиблена переробка природних ресурсів повинна приносити не лише соціально-економічну вигоду, а й сприяти збереженню навколишнього природного середовища, сприяти покращенню його екологічного стану.

Впровадження інновацій (зокрема, інноваційного обладнання) у виробничу діяльність підприємств харчової та деревообробної сфер промисловості Волинської області зумовлює зниження викидів шкідливих речовин й відходів у навколишнє природне середовище, але потрібно звернути увагу, що сьогодні відсутні прямі стимули з боку органів державної, регіональної та місцевої влади, щоб заохочували промислові підприємства використовувати «екологічно чисте» обладнання та дотримуватися «екологічної доброчесності».

Тому пропонується для зниження обсягів викидів шкідливих речовин й відходів переробних підприємств Волинської області додатково використовувати такі фінансовоекономічні інструменти:

1) заохочувального характеру (коли щорічний показник співвідношення обсягів реалізації продукції підприємствами, що переробляють місцеву природно-ресурсну сировину до сумарного обсягу відходів виробництва й викиду шкідливих речовин більший за середне зважене (планове, прогнозне) значення) - компенсація податку на прибуток та екологічного податку; збільшення фінансових виплат та компенсація інших нарахованих податків з місцевого та державного бюджетів; компенсація за придбання інноваційного «екологічно чистого» обладнання тощо;

2) карального характеру (коли щорічний показник співвідношення обсягів реалізації продукції підприємствами, що переробляють місцеву природно-ресурсну сировину до сумарного обсягу відходів виробництва й викиду шкідливих речовин більший за середнє зважене (планове, прогнозне) значення) - підвищення ставок екологічного податку; впровадження (нарахування) додаткових податків та зборів екологічного характеру; удосконалення екологічного законодавства (слід переглянути й скоригувати еколого-економічні норми в вітчизняному природоохоронному законодавстві таким чином, щоб вони відповідали сучасним реаліям та здійснювали жорсткий відчутний вплив на суб'єкти природокористування); підвищення тарифів на електроенергію та паливні ресурси для переробних підприємств тощо.

Подальші дослідження у напрямку створення та розвитку переробних виробництв із поглибленої переробки природних ресурсів, зменшення обсягів викидів шкідливих речовин та відходів, повинні розглядати питання удосконалення вже наявного нормативно-правового законодавства стосовно забезпечення належного рівня охорони навколишнього середовища, встановлення жорстких штрафів (покарання) за порушення екологічних норм та правил тощо. Особливої уваги потребує питання щодо пошуку шляхів залучення фінансових ресурсів необхідних для закупівлі та подальшого використання на промислових підприємствах регіону «екологічно чистого» інноваційного обладнання.

\section{Список бібліографічного опису}

1. Домбровська С. М., Коврегін В. В., Помаза-Пономаренко А. Л., Колєнов О. М. Державне управління у сфері безпеки соціально-еколого-економічних систем : монографія. Харків : НУЦЗУ, 2017. 244 с.

2. Латишева О. В., Касьянюк С. В., Касьянюк О. С. Аналіз результативності впровадження природоохоронних заходів регіонального розвитку України. Економічний вісник Донбасу. 2018. № 2 (52). С. 72-78. 
3. Теребух А. А., Ільницька-Гикавчук Г. Я., Макар О. П. Фінансування природоохоронних заходів в Україні. Вісник Хмельнииького наиіонального університету. 2015. № 5. Т. 1. С. 108-111.

4. Файчук О. В. Ключова проблема фінансової підтримки інноваційних проектів - недосконалість вітчизняного законодавства. Економіка. Фінанси. Право. 2013. № 2. С. 21-24.

5. $\quad$ Поліщук В. Г. Перспективи податкового стимулювання сталого розвитку регіонів України. Економіка та держава. 2010. № 4. С. 59-61.

6. Карлін М. І. Форми фінансового стимулювання екологічної відповідальності бізнесу, територіальних громад і громадян. Демографія та соиіальна економіка. 2017. № 2 (31). С. 89-99.

7. Нешик С. С. Принципи правового забезпечення державного управління у сфері раціонального використання природних ресурсів. Наукові записки Інституту законодавства Верховної Ради України. 2014. № 2. С. 170-174.

8. 229. Сяська О. В. Аналіз зарубіжного досвіду регулювання процесів водокористування та перспективи його застосування в Україні. Економічні науки. Сер. : Економіка та менеджмент. 2013. Вип. 10. С. 213-224.;

9. Косінський П. М. Економічне стимулювання розвитку переробних виробництв на базі природно-ресурсних комплексів Волинської області : дис. ... д-ра філософії за спеціальністю 051 Економіка : 32.075.001. Луцьк, 2020. 311 с. 10. Шубалий О. М., Косінський П. М. Економічне стимулювання комплексної переробки природних ресурсів у регіоні : монографія. Луцьк : ІВВ Луцького НТУ, 2019. 218 с.

11. Статистичний щорічник Волинь 2010 / за ред. М. І. Мотиль. Луцьк : Головне управління статистики у Волинській області, 2011.570 с.

12. Статистичний щорічник Волинь 2014 / за ред. В. Ю. Науменка. Луцьк : Головне управління статистики у Волинській області, 2015. 490 с.

13. Статистичний щорічник Волинь 2018 / за ред. В. Ю. Науменка. Луцьк : Головне управління статистики у Волинській області, 2019. 443 с.

14. Промисловість Волині 2018 / за ред. Л. С. Баранюк. Луцьк : Головне управління статистики у Волинській області, 2019. 64 с.

\section{References}

1. Dombrovs'ka S. M., Kovrehin V. V., Pomaza-Ponomarenko A. L., Kolyenov O. M. (2017). Derzhavne upravlinnya u sferi bezpeky sotsial'no-ekoloho-ekonomichnykh system : monohrafiya [State management in the field of security of socioecological and economic systems: a monograph]. Kharkiv : NUTSZU [in Ukrainian].

2. Latysheva O. V., Kas'yanyuk S. V., Kas'yanyuk O. S. (2018). Analiz rezul'tatyvnosti vprovadzhennya pryrodookhoronnykh zakhodiv rehional'noho rozvytku Ukrayiny [Analysis of the effectiveness of environmental protection measures for regional development of Ukraine]. Ekonomichnyy visnyk Donbasu - Economic Bulletin of Donbass, 2. 72-78.

3. Terebukh A. A., Il'nyts'ka-Hykavchuk H. YA., Makar O. P. (2015). Finansuvannya pryrodookhoronnykh zakhodiv v Ukrayini [Financing of environmental measures in Ukraine]. Visnyk Khmel'nyts'koho natsional'noho universytetu - Bulletin of Khmelnytsky National University, 5. 108-111.

4. Faychuk O. V. (2013). Klyuchova problema finansovoyi pidtrymky innovatsiynykh proektiv - nedoskonalist' vitchyznyanoho zakonodavstva [he key problem of financial support of innovative projects is the imperfection of domestic legislation]. Ekonomika. Finansy. Pravo - Economy. Finances. Right, 2. 21-24.

5. Polishchuk V. H. (2010). Perspektyvy podatkovoho stymulyuvannya staloho rozvytku rehioniv Ukrayiny [Prospects for tax incentives for sustainable development of the regions of Ukraine]. Ekonomika ta derzhava-Economy and state, 4. 59-61.

6. Karlin M. I. (2017). Formy finansovoho stymulyuvannya ekolohichnoyi vidpovidal'nosti biznesu, terytorial'nykh hromad i hromadyan [Forms of financial incentives for environmental responsibility of business, local communities and citizens.]. Demohrafiya ta sotsial'na ekonomika - Demography and social economy, 2. 89-99.

7. Neshyk S. S. (2014). Pryntsypy pravovoho zabezpechennya derzhavnoho upravlinnya u sferi ratsional'noho vykorystannya pryrodnykh resursiv [Principles of legal support of public administration in the field of rational use of natural resources]. Naukovi zapysky Instytutu zakonodavstva Verkhovnoyi Rady Ukrayiny - Scientific notes of the Institute of Legislation of the Verkhovna Rada of Ukraine, 2. 170-174.

8. 229. Syas'ka O. V. (2013). Analiz zarubizhnoho dosvidu rehulyuvannya protsesiv vodokorystuvannya ta perspektyvy yoho zastosuvannya $\mathrm{v}$ Ukrayini [Analysis of foreign experience in regulating water use processes and prospects for its application in Ukraine]. Ekonomichni nauky. Ser. : Ekonomika ta menedzhment - Economic sciences. Ser. : Economics and Management, 10. 213-224.;

9. Kosins'kyy P. M. (2020). Ekonomichne stymulyuvannya rozvytku pererobnykh vyrobnytstv na bazi pryrodno-resursnykh kompleksiv Volyns'koyi oblasti [Economic Incentives of the Development of Processing Industry on the Basis of Natural Resource Complexes of Volyn Region]. Dis. ... Doctor of Philosophy, specialty 051 Economics. 32.075.001. Luts'k [in Ukrainian].

10. Shubalyy O. M., Kosins'kyy P. M. (2019). Ekonomichne stymulyuvannya kompleksnoyi pererobky pryrodnykh resursiv u rehioni : monohrafiya [Economic stimulation of complex processing of natural resources in the region: monograph]. Luts'k : IVV Luts'koho NTU [in Ukrainian].

11. Motyl' M. I. (2011). Statystychnyy shchorichnyk Volyn' 2010 [Statistical Yearbook of Volyn 2010]. Luts'k : Holovne upravlinnya statystyky u Volyns'kiy oblasti [in Ukrainian].

12. Naumenko V. Yu (2015). Statystychnyy shchorichnyk Volyn' 2014 [Statistical Yearbook of Volyn 2014]. Luts'k : Holovne upravlinnya statystyky u Volyns'kiy oblasti [in Ukrainian].

13. Naumenko V. Yu (2019). Statystychnyy shchorichnyk Volyn' 2018 [Statistical Yearbook of Volyn 2018]. Luts'k : Holovne upravlinnya statystyky u Volyns'kiy oblasti [in Ukrainian].

14. Baranyuk L. S. (2019). Promyslovist' Volyni 2018 [Industry of Volyn 2018]. Luts'k : Holovne upravlinnya statystyky u Volyns'kiy oblasti [in Ukrainian].

Дата подання публікації 20.12.2020 р. 